\title{
Особенности спектральных характеристик георадиолокационных сигналов, полученных при зондировании речного песка в мерзлом и талом состоянии
}

\author{
Аммосов А.П., аспирант, \\ Институт горного дела Севера им. Н.В. Черского СО РАН, \\ 2. Якутск \\ E-mail: yakoot@inbox.ru
}

Научный руководитель: к.т.н. Саввин Д.В.

При строительстве и эксплуатации инженерно-технических сооружений следует знать физико-механические свойства грунтов их оснований. Эти свойства, в условиях криолитозоны, в основном зависят от содержания влаги. Для получения этой информации необходима разработка методов оперативного и дистанционного определения влажности грунтов. Например, на основе такого геофизического метода, как георадиолокация, который весьма эффективен при изучении криогенного состояния грунтов и дисперсных горных пород, при этом спектральные характеристики георадиолокационных сигналов существенно зависят как от их влажности, так и температуры [1-5].

Для изучения зависимости спектральных характеристик георадиолокационных сигналов от влажности и от температуры дисперсных горных пород, были проведены экспериментальные исследования в ИГДС СО РАН. Частотная дисперсия мерзлой горной породы определяется поляризационными и кинетическими процессами, зависящими от структуры порового пространства, от свойств порового раствора и минерального скелета горных пород, давления, температуры и т. д. Измерения свойств пород в натуральных условиях по системе мониторинга позволяют устанавливать корреляционные зависимости электрофизических свойств массива естественного залегания от его физического состояния мерзлого массива [6]. Для проведения экспериментального исследования был выбран наиболее распространенный однородный материал возле реки Лена, песок аллювиального геолого-генетического типа. Размер зерен песка определялся ситовым методом, согласно ГОСТ 12536-2014 [7]. По полученным данным о гранулометрическом (зерновом) составе установлено, что исследуемый образец - песок мелкой крупностью. Данный песок был помещен в ящик из ДСП с размерами 0,5 м высоту, 0,5 м ширину и 0,25 м в длину. Определение влажности песка осуществлялось согласно ГОСТ 5180-84 [8]. Готовые образцы с различной влажностью, в количестве шести штук, поочередно замораживались в холодильной камере «Castlcool» до температуры $-15^{\circ} \mathrm{C}$. Затем мерзлый образец был извлечен из холодильной камеры. Температура комнаты в момент начала опыта составляла $+23^{\circ} \mathrm{C}$. Полная оттайка образцов длилась от 12 до 36 часов. Исследование образцов проводилось контактным зондированием георадаром «ОКО-2» с центральной частотой 1200 МГц [9]. Для точности измерения температуры песка использовались три цифровых термометра «CENTER-314» равноудаленных друг от друга и на разных расстояниях от дна короба. Исследование образца происходило каждые тридцать минут.

Исследуемая экспериментальная модель состоит из двух слоев. Первым слоем служит мелкозернистый песок мощностью 0,25 м, вторым слоем является воздух, 
толщина слоя принимается как бесконечная, исходя из условий проведения эксперимента и параметров георадиолокационного зондирования. Запись и обработка георадиолокационных сигналов проводилась программой «GeoScan32» [10]. Зондирования проведены в дискретном и непрерывном режимах с параметрами: накопление сигналов - 128; количество точек по глубине - 511; развертка по глубине 16 нс. При выбранном режиме записи радарограмм шаг дискретизации, (точность регистрации времени задержки), составил 0,03 нс. В данном опыте регистрировалось двойное время $(\mathrm{t}, \mathrm{Hc})$ затраченное на прохождение электромагнитного сигнала сквозь образец до границы «песок-воздух». Но основным предметом исследования являются характеристики амплитудно-частотного спектра от той же границы.

Выявлено, что частотный спектр, полученный по результатам зондирования мелкозернистого песка для отрицательных температур, мало зависит от влажности образца и находится в диапазоне от 938 МГц до 1125 МГц. В талой зоне с повышением влажности мелкозернистого песка максимальное значение спектра изменяется от 594 МГц до 781 МГц. Такая же зависимость наблюдается от ширины спектра ( $\Delta \mathrm{f}$, МГц) георадиолокационного сигнала. При мерзлом состоянии ширина спектра лежит в диапазоне от 1375 МГц до 1594 МГц, а в талом ширина спектра находится в диапазоне частот от 875 МГц до 1125 МГц.

Полученные результаты позволяют использовать метод георадиолокации для изучения криогенного состояния дисперсных горных пород на основе анализа спектральных характеристик георадиолокационных сигналов.

\section{Список литературы:}

1. Jol. M. Harry. Ground Penetrating Radar Theory and Applications, Elsevier Science, p. 543, 2009.

2. Нерадовский Л.Г. Температурная зависимость сигналов георадиолокации в освоенных районах криолитозоны Якутии. Якутск: Изд-во Института мерзлотоведения им. П.И. Мельникова СО РАН, С. 166, 2011.

3. Фролов А.Д. Электрические и упругие свойства мерзлых пород и льдов. Пущино: ОНТИ ПНЦ РАН, С. 607, 2005.

4. K. Sokolov. Capabilities of the wavelet analysis of GPR data to determine the rock moisture in frozen rock mass. Proceedings of the 14th International Conference on Ground Penetrating Radar June 4-8, 2012, Shanghai, China, Vol.2, pp. 358-361

5. Шувалов А.Н., Гензе Д.А. Диэлектрическая проницаемость грунтов нарушенной структуры. Вестник ТГАСУ, №1. - С. 200-206, 2011.

6. Омельяненко А.В. Георадиолокационные исследования многолетнемерзлых пород / А.В. Омельяненко, Л.Л. Федорова // - Якутск: Изд-во ЯНЦ СО РАН - 2006. $136 \mathrm{c.}$

7. ГОСТ 12536-2014 Грунты. Методы лабораторного определения гранулометрического (зернового) и микроагрегатного состава [Текст]. - ГОСТ 1253679; Введ. 01.07.1980. - М.: Стандартинформ, С. 19, 2015.

8. ГОСТ 5180 - 84 Грунты. Методы лабораторного определения физических характеристик [Текст]. - Взамен ГОСТ 5180-75; Введ. 30.06.1985. - М.: Стандартинформ, С. 19, 2005.

9. Техническое описание и инструкция по эксплуатации на Георадар "ОКО-2". Режим доступа / http://geotech.ru/files/georadar/gprtov26beta303.pdf 
10. Руководство пользователя программой GeoScan32. - Режим доступа / http://logsys.ru/download/new/geoscan32manual.pdf

\title{
Вторичное дробление негабаритов при разработке кимберлитовой трубки «Заря»
}

\author{
Анисимов А.Н., студент, \\ Технический институт (филиал) \\ Северо-Восточного федерального университета, \\ 2. Нерюнгри \\ E-mail: anisimov.ayaal@mail.ru
}

Научный руководитель: д.m.н., профессор Гриб Н.Н.

Кимберлитовая трубка «Заря» находится на юго-западной окраине Анабарской антеклизы в зоне сочленения с Тунгусской синеклизой, где широко развиты нижнепалеозойские карбонатные породы, перекрытые на значительной части верхнепалеозойскими терригенными отложениям, интрудированными и бронированными нижнетриасовыми породами трапповой формации.

Кимберлитовая трубка «Заря» полностью перекрыта толщей терригенных образований каменноугольного возраста и породами траппового комплекса пермотриаса.

Мощность перекрывающих трубку пород варьирует от 84,8 м на северо-западном фланге до 114 м на юго-восточном, в среднем составляя 103 м. [1].

Терригенные отложения, ранее перекрывавшие кимберлитовое тело, практически полностью уничтожены интрузией долеритов и сохранились лишь фрагментарно в углублениях на поверхности рудного тела, либо в виде оторванных и приподнятых блоков. Представлены они преимущественно разнозернистыми песчаниками айхальской свиты с прослоями алевролитов, углистых алевролитов. Мощность терригенных отложений колеблется от 7,4 м до 31,6 м.

Основная часть разреза перекрывающих пород представлена разнокристаллическими долеритами первой фазы внедрения. Максимальная мощность траппов над трубкой составляет 111,6 м, минимальная - 14 м (рис. 1) [1].

На различных уровнях геологического разреза залегают туфогенные образования, представленные в основном туфами основного состава, реже туфопесчаниками (от 2,0 до 12,0 м). Суммарная мощность их достигает 82,5 м.

Коэффициент крепости перекрывающих долеритов по шкале проф. М.М. Протодьяконова составляет 7-9. Объемный вес перекрывающих пород колеблется от 2,6 до 3,0 т/ $\mathrm{m}^{3}$. Коэффициент крепости туфогенных образований по шкале проф. М.М. Протодьяконова составляет 4-5 [2].

В результате геологической неоднородности перекрывающих пород и рудных тел, а также больших колебаний прочности пород, от 40 до 90 мПа, в процессе буровзрывных работ, часто образуются негабариты [2]. Одним из методов разделки негабаритов является вторичное дробление. 